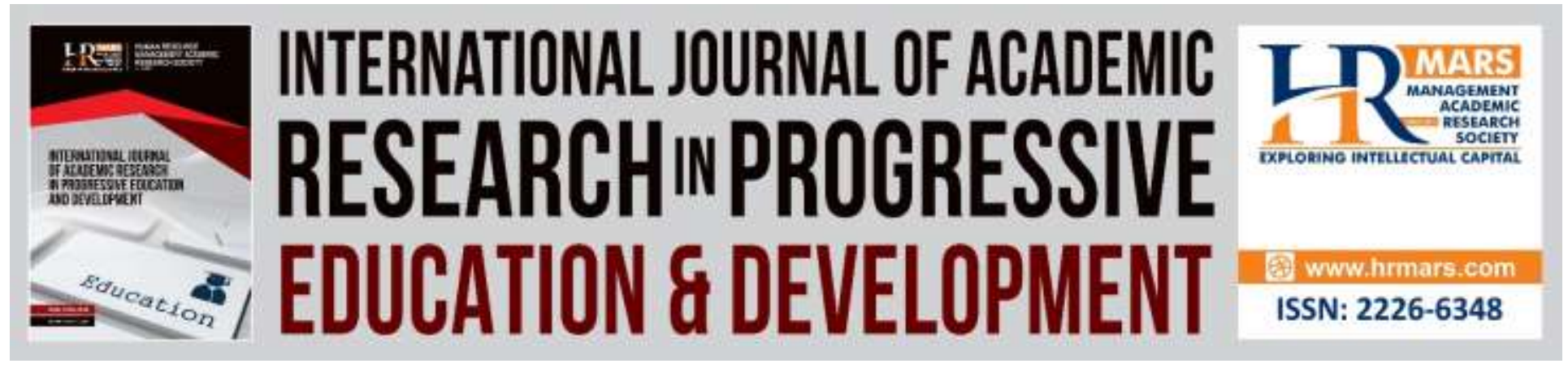

\title{
A Review of E-Portfolios in Malaysian Higher Education
}

\author{
Wirawati Ngui Yi Xe, Vincent Pang, Wendy Hiew
}

To Link this Article: http://dx.doi.org/10.6007/IJARPED/v8-i4/6515

DOI:10.6007/IJARPED/v8-i4/6515

Received: 13 October 2019, Revised: 21 October 2019, Accepted: 31 October 2019

Published Online: 12 November 2019

In-Text Citation: (Ngui, Pang, \& Hiew, 2019)

To Cite this Article: Ngui, W. Y. X., Pang, V., \& Hiew, W. (2019). A Review of E-Portfolios in Malaysian Higher Education. International Journal of Academic Research in Progressive Education and Development, 8(4), 301-311.

\section{Copyright: (C) 2019 The Author(s)}

Published by Human Resource Management Academic Research Society (www.hrmars.com)

This article is published under the Creative Commons Attribution (CC BY 4.0) license. Anyone may reproduce, distribute, translate and create derivative works of this article (for both commercial and non-commercial purposes), subject to full attribution to the original publication and authors. The full terms of this license may be seen

at: http://creativecommons.org/licences/by/4.0/legalcode

\section{Vol. 8(4) 2019, Pg. 301 - 311}

Full Terms \& Conditions of access and use can be found at http://hrmars.com/index.php/pages/detail/publication-ethics 


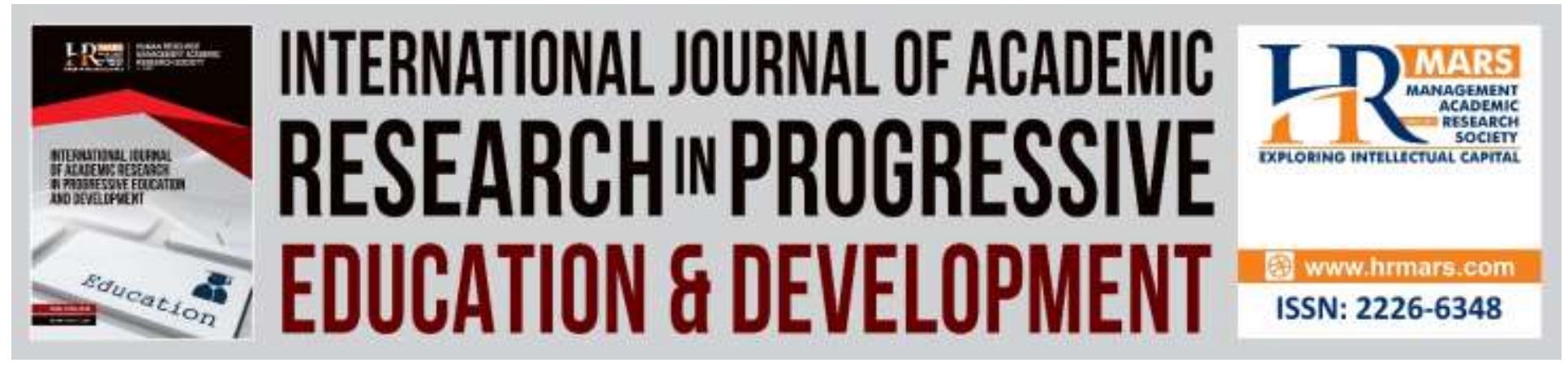

\title{
A Review of E-Portfolios in Malaysian Higher Education
}

\author{
Wirawati Ngui Yi Xe ${ }^{1}$, Vincent Pang ${ }^{2}$, Wendy Hiew ${ }^{1}$ \\ ${ }^{1}$ Centre for the Promotion of Knowledge and Language Learning, Universiti Malaysia Sabah, \\ 88400 Kota Kinabalu, Sabah, Malaysia, ${ }^{2}$ Faculty of Psychology and Education, Universiti \\ Malaysia Sabah, 88400 Kota Kinabalu, Sabah, Malaysia
}

\begin{abstract}
Technology has enhanced methods and resources to teach and assess learners. An example is the e-Portfolio, a tool that has the ability to accommodate a plethora of digital learning evidences. Due to its digital nature, the e-Portfolio also enables easy access to a wide range of stakeholders. Thus, e-Portfolios have gradually replaced paper-based portfolios as a more relevant educational tool. This trend is also evident in Malaysia whereby academicians and researchers have explored the use of e-Portfolio in higher learning institutions. A review is therefore timely to provide an overview of the present state of knowledge. This study aims to present a review of empirical research involving e-Portfolios in the Malaysian higher education context. As such, the review takes into account a range of studies involving various stakeholders, programmes, and higher learning institutions. The study provides a comprehensive overview of the e-Portfolio studies that have been conducted thus far and reveals the contributions of ePortfolio as an educational tool in Malaysia.
\end{abstract}

Keywords: E-Portfolio, Higher Education, Malaysia, Blended Learning, E-Learning

\section{Introduction}

The Malaysian government has included technology as an essential aspect of teaching and learning, and e-learning has become an integrated component across Malaysian higher learning institutions (Ministry of Education, 2013). An example of a technologically enhanced tool is the e-Portfolio (electronic portfolio). E-Portfolios have been adapted across different countries including Australia (Education Department of Western Australia, 2000), New Zealand (New Zealand Ministry of Education, 2011), and the United States of America (Lorenzo \& Ittelson, 2005). An e-Portfolio is a compilation of students' work that may be published on the World Wide Web (Sadia, 2005); this collection comprises "artefacts" such as images, audio and video files that relate to the learning goals, all of which reflects the learners' progress over a period of time (Challis, 2005; Krause, 2006; New Zealand Ministry of Education, 2011). An e-Portfolio may also incorporate word-processed documents, graphic organisers, online articles as well as blogs, supported by a range of digital evidences (Stannard \& Basiel, 2013), which 
Vol. 8, No. 4, 2019, E-ISSN: 2226-6348 @ 2019 HRMARS

altogether proves and displays students' abilities and attainments (Cooper, 1999). This innovative tool has gained gradual popularity in Malaysia and this was further reflected by the Ministry of Education's decision to pilot test e-Portfolios in ten secondary schools commencing the year 2019 (Chin, 2018).

Although the exploration of innovative tools is commendable, various teaching and learning matters such as context, programmes, and policies need to be taken into account. This is especially pertinent since the use of e-Portfolios is still relatively novel in Malaysia. Therefore, a review of the e-Portfolio studies that have been conducted in Malaysia thus far is essential to provide researchers with an overview of the present state of knowledge.

\section{E-Portfolios}

A modernized version of paper-portfolio is the e-Portfolio; this comprises an individual or a group of people's collection of evidence, demonstrating their abilities and attainments, and can be stored on a website or in a portable storage device such as a CD-ROM or DVD-ROM (Lorenzo \& Ittelson, 2005; Challis, 2005). The features of e-Portfolio are presented in Table 1.

\section{Table 1}

\section{Features of E-Portfolio}

\begin{tabular}{|l|l|}
\hline \multicolumn{1}{|c|}{ Features } & \multicolumn{1}{|c|}{ Details } \\
\hline Digital resources & $\begin{array}{l}\text { Artefacts that are text-based, multimedia or graphic (student } \\
\text { reflection, instructor feedback, audio, video, podcasts, mind maps, } \\
\text { pictures) which represent learning and prove attainments }\end{array}$ \\
\hline Adaptable & $\begin{array}{l}\text { Customisable for different purposes such as to reflect learning } \\
\text { outcomes or for achieving specific tasks }\end{array}$ \\
\hline Accessible & $\begin{array}{l}\text { Ease of access for a range of stakeholders (peers, instructors, local } \\
\text { community, academicians, researchers, prospective employers) }\end{array}$ \\
\hline $\begin{array}{l}\text { Storage/ } \\
\text { Management }\end{array}$ & Suitable software; CD-ROM or DVD-ROM, web environment \\
\hline
\end{tabular}

Note. Adapted from "E-Portfolios for Graduate Students: A Discussion Paper" by K. Krause, 2006, Centre For the Study of Higher Education, University of Melbourne.

The features shown in Table 1 are the qualities that set e-Portfolios apart from conventional portfolios. An e-Portfolio includes a collection of digital materials, provides flexibility based on its purpose, is widely accessible to relevant parties, and should be easily transferable or made available via the web. As such, various online platforms have either been specifically developed or strategically utilized for e-Portfolio purposes. Examples of specific ePortfolio platforms include Mahara and Digication whereas cloud storage service such as Google Drive has also been employed as a form of e-Portfolio (Carl, 2016).

Despite the fact that the concept of e-Portfolio evolved from paper-based portfolio, various distinctive features set the two apart (Barrett, 2005; Challis, 2005; New Zealand Ministry of Education, 2011). In comparison, the e-Portfolio is superior in terms of mobility, accessibility, sustainability, and wider viewership; it also includes a range of multimedia artefacts, inculcates reflection, and allows assessments to be done both formatively and summative (New Zealand 
Ministry of Education, 2011). Apart from that, e-Portfolios are inexpensive and user-friendly, and allow the merging of a multitude of digital materials, (Greenberg, 2004). Furthermore, ePortfolios offer greater flexibility as they can be revised, transferred, and navigated as compared to paper-based portfolios (Krause, 2006).

Researchers have classified e-Portfolios into different categories befitting their respective purposes and contexts such as e-Portfolios for education, for career, and also for accreditation purposes. Greenberg (2004) categorized e-Portfolios into three types in relation to when the work is sorted and created, as shown in Table 2.

\section{Table 2}

Types of E-Portfolio

\begin{tabular}{|c|c|}
\hline Portfolio type & Description \\
\hline Showcase e-Portfolio & $\begin{array}{l}\text { - Work is created then sorted } \\
\text { - Can be used for education and work opportunities } \\
\text { - Demonstrates individual learning experiences which provides } \\
\text { context for discussion and reflection }\end{array}$ \\
\hline Structured e-Portfolio & $\begin{array}{l}\text { - Prearranged structure prior to the creation of work } \\
\text { - Specific requirements to be fulfilled such as formal objectives/ } \\
\text { outcomes to demonstrate attainments/ skills }\end{array}$ \\
\hline Learning e-Portfolio & $\begin{array}{l}\text { - Creation and sorting of work occurs simultaneously } \\
\text { - Work is flexibly reorganised from time to time depending on } \\
\text { the author's changing personal learning experience }\end{array}$ \\
\hline
\end{tabular}

Note. Adapted from “The Digital Convergence: Extending the Portfolio Model” by G. Greenberg, 2004, EDUCAUSE Review, 39(4), 28-37.

Table 2 presents the three types of e-Portfolios as proposed by Greenberg (2004). This classification provides practitioners with some insights regarding the types of portfolios which could be implemented in accordance with context and program. On the other hand, Lorenzo and Ittelson (2005) categorized e-Portfolios into three general types: for students, for teachers, and for institutions. Student e-Portfolios can accomplish numerous aims: develop writing, multimedia communication, critical thinking, and technology literacy skills. Apart from academic advantages, student e-Portfolios can be useful for demonstrating product and accomplishments to potential employers. Teaching e-Portfolios showcase teachers' work among students, colleagues and the community; and are also valuable for the sharing of knowledge and best practices when made public. Institutional e-Portfolios represent a detailed collection of information (student ePortfolios, teaching e-Portfolios, and other e-Portfolios) which serves accreditation and accountability purposes.

\section{Research on e-Portfolios in the Malaysian Higher Education Context}

Malaysian researchers have demonstrated a keen interest to explore the use of e-Portfolios particularly in higher learning institutions. This could be due to the fact that e-Portfolios offer 
greater flexibility and accessibility to both instructors and learners. The following are some of the empirical studies involving e-Portfolios that have been conducted thus far.

\section{E-Portfolio Features and Functions}

Studies have highlighted prominent features and functions of e-Portfolio for future implementation. One of the significant features of e-Portfolio was the incorporation of authentic digital learning evidences (Syamsul, Mohamed, \& Norazah, 2015b; Abd-Wahab, Che-Ani, Johar, Ismail \& Abd-Razak, 2016). Syamsul et al.'s (2015b) study identified e-Portfolio elements using the Fuzzy Delphi method for the context of art and design. This method was divided into three phases whereby the first phase involved the interviewing of seven experts from various higher learning institutions in order to identify emerging themes for the development of the "e-Portfolio Consensus Survey". The second phase required 16 instructional technology experts to respond to the survey. The data were then analysed in the third phase by calculating the consensus score. The findings revealed that the respondents ranked evidence-based, authenticity, and metacognitive skills as the three most important e-Portfolio elements. On the other hand, AbdWahab et al.'s study (2016) examined the contents and challenges for implementing e-Portfolio. Data were collected by distributing a Google survey form to 100 respondents consisting of students and staff from Malaysian higher learning institutions. The sample consisted mainly of students (79\%) and as many as $76 \%$ of the respondents were from an engineering background. Notable findings include the fact that a majority of the respondents agreed that using e-Portfolio can contribute to making students' learning process more evident, and selection of learning evidences is an important criterion of assessment. Apart from that, a majority of the respondents ranked academic materials from their main program of study as the foremost e-Portfolio content, followed by authentic industry experiences.

Building on their previous work, Syamsul, Mohamed and Norazah (2016) examined ePortfolio functions for higher education by gathering the opinions of 25 instructional technology experts. The findings confirmed the three functions of e-Portfolio are for storage, workspace, and showcase. As a storage, students have the ability to update, revise and make a backup of resources and content that are stored digitally. As a workspace, the e-Portfolio allows students to present digital evidences as proof of learning. As a showcase, students' talent and work can be demonstrated via the e-Portfolio which is also easily accessible to employers and other stakeholders. The study provided a comprehensive overview of some of the primary e-Portfolio functions in the higher education context.

\section{E-Portfolio and Student Readiness}

Research further suggests that the introduction of e-Portfolios in Malaysian higher learning institutions is timely and relevant. A study conducted in Universiti Kebangsaan Malaysia (UKM) investigated students' readiness to adopt e-Portfolio (Syamsul, Mohamed \& Norazah, 2015a). The study included 300 coursework students from the Faculty Education, Faculty of Art and Design, and Faculty of Film, Theater and Animation (Social Science and Humanities). The items in the questionnaire attempted to determine students' readiness to adopt e-Portfolio in aspects of (1) technology accessibility, (2) online skills and relationship, (3) motivation, (4) internet discussion, and (5) importance to success. The researchers concluded that the respondents were 
prepared to use e-Portfolio as a learning tool and added that specific instructional design and educational strategy should be taken into account for the implementation of e-Portfolios. Another study that was conducted with a focus on Technical and Vocational Education Training (TVET) similarly reported positive responses towards the implementation of e-Portfolios in the Malaysia Skills Training Program (Hafizan, Duggan, Tracy \& Stott, 2015). The study employed a combination of survey and interview, and took into account the perception of administrative and academic staff as well as students. Apart from unanimous support from the staff, the researchers revealed that as many as $90 \%$ of the students agreed to the implementation of e-Portfolio.

\section{E-Portfolio Motivational Factors}

For academicians and educators who are keen to embrace e-Portfolio as part of classroom practices, it is pertinent to consider the factors that can serve to motivate learners. Rokhsareh, Azizah and Mojib (2015) investigated motivational factors of using e-Portfolios from undergraduate students' perspective. As a result of interviewing 15 respondents from the chemical engineering, civil engineering, and computing programs, the researchers discovered a total of eight motivational factors namely information quality, system quality, consequences of use, learner competence, social norms, positive feedbacks, ownership, and service quality.

\section{E-Portfolio as an Assessment}

Apart from serving the purpose of teaching and learning, e-Portfolios can also operate as a tool for assessment. Abd-Wahab, Che-Ani, Johar, Ibrahim, Ismail and Mohd-Tawil (2016) analysed the rubric criteria of e-Portfolio as a form of assessment in six American universities. The study defined e-Portfolio as a tool for gathering various digital artefacts, allowing learners to present their work through electronic mediums. By collecting data across the six American universities (Clemson University, University of Wisconsin-Stout, Boston University-College of General Studies, Loyola University Chicago, San Francisco State University, and Draka University) and comparing the respective rubric criteria, the researchers were able to come up with an innovative basic assessment framework which was deemed best fit for the implementation of e-Portfolio in the Malaysian context. While the review served as a reference point for assessing students' competency using e-Portfolios, this was demonstrated in a generic manner (learning programme or course was not specified). In actual fact, the implementation of e-Portfolio across different courses would essentially entail variations in the rubric criteria.

\section{E-Portfolio Development}

The development of e-Portfolio based on the experiences of instructional designers was revealed in a study about iCollect, a mobile application for e-Portfolio (Mohd, Muhammad, Nuraihan, Haslina \& Mohaida, 2014). Using the rapid prototype model, the researchers were able to produce iCollect for the purpose of learning Arabic language and subsequently pilot tested the application. The respondents consisted of 38 students at the International Islamic University Malaysia who provided feedback for iCollect by ranking the features. As a result, the study confirmed the usability of iCollect as an e-Portfolio for the teaching and learning of languages. Another significant contribution of this study was the expansion of scope from computer to 
smartphone. This is perhaps an even more appealing and relevant prospect considering the current generation's reliance on smartphones.

\section{E-Portfolio in the ESL Context}

Research on the use of e-Portfolios in the ESL context has established its contribution to reflective practice. Thang, Lee and Nurul, (2012) explored the implementation of e-Portfolio to enhance Information and Communication Technology (ICT) and English language skills among undergraduate students at Universiti Kebangsaan Malaysia (UKM). Students were required to develop an e-Portfolio as part of the requirement for the Technology and Innovation in TESL course which was offered as an elective subject by the School of Language Studies and Linguistics. Following the 10-week project, researchers interviewed six students to determine the ePortfolio's impact. The study concluded that the students perceived themselves to have gained in terms of skills related to technology and problem solving. The participants also expressed that in terms of language, their writing skills had improved. The researchers attributed the achievements to the students' reflective practice which led to improved autonomy in the learning process. Another study that was conducted at UKM similarly recognised the potential for reflective practice using e-Portfolio (Nambiar \& Melor, 2017). A total of 20 undergraduate students who were enrolled in the Teaching English as a Second Language (TESL) programme were involved in the study. The respondents produced written reflections of their school observation experiences via their respective e-Portfolios. The findings indicated that the ePortfolio was able to support the students' reflective practice through the documentation and sharing of their experiences in a virtual environment.

\section{E-Portfolio and Graduate Skills}

Studies have also explored the use of e-Portfolios for the purpose of enhancing graduate skills. Hafizan, Duggan, Tracy and Stott's (2015) study investigated the suitability and potential of implementing e-Portfolio for TVET. To identify the perception of experts, one of the data collection methods involved the interview of ten respondents that consisted of three instructors, two principals and five government officers who were involved in the Malaysia Skills Training Program. In relation to e-Portfolio use, the respondents expressed agreement over the enhancement of skills and knowledge in computer and information technology as well as the development of reflective practice. On the other hand, Khoo, Maor and Schibeci (2011) examined the use of e-Portfolio to enhance the graduate attributes of engineering students. The researchers analyzed the perception of 66 students with regard to their e-Portfolio experience using two sets of questionnaires. The findings revealed that using e-Portfolio contributed to the following skills: collaboration, problem solving, critical thinking, and communication. As such, the study indicated the e-Portfolio's potential for the purpose of developing the graduate attributes of university students.

\section{E-Portfolio for Professional Development}

The use of e-Portfolio among teachers has gained popularity and proven to contribute to pre-service and in-service teachers' professional development. In a study conducted at Universiti Sains Malaysia, 91 pre-service teachers used Facebook as an e-Portfolio as part of the 
Information and Communication Technology in Education course (Muhammad, 2016). The study revealed that the use of e-Portfolio supported the pre-service teachers' professional development particularly in aspects of community of practice, professional learning and identity, relevant skills, resources, and confidence. The contribution of e-Portfolio towards professional development was similarly established in a study involving twenty teachers (Shalini, Wan, Mahani \& Mohamad, 2012). Furthermore, the respondents expressed that their computer skills had improved as a result of developing their respective e-Portfolios. This was attributed to the sharing of knowledge and practice with other instructors via the virtual platform. Although the respondents were in-service teachers and were therefore not essentially link to the higher education context, the study serves as a reference for using experience-based e-Portfolio in profession and career-related university programs.

\section{Discussion}

The e-Portfolio is a tool that can cater to various uses for instance to display work, to store learning evidences, and to demonstrate progress. As indicated by the studies, it is pertinent for educators to identify the primary features and functions that align with the intended content and program.

Based on the fact that the aforementioned studies involved a variety of programs and higher learning institutions, the findings have thus far indicated that e-Portfolios can be tailored to suit specific purposes and content. By incorporating the insights of experts as well as learners, the studies further conveyed the importance of developing contextspecific e-Portfolios. As such, devising an e-Portfolio that befits the purpose and context of the intended group of learners should be made a priority.

Apart from content, purpose and context, the studies revealed that readiness and motivational factors are significant aspects that may affect the learners' use of the e-Portfolio. Considering that learners in different institutions may vary greatly in terms of background and proficiency, learner readiness and motivational factors should be taken into account when introducing the e-Portfolio to new students.

Although e-Portfolios are typically associated with computers, Malaysian instructional designers further expanded its use to smartphones. This intensified the accessibility and convenience of using e-Portfolios as part of learning. In addition, young learners may also find using e-Portfolio on smartphones more engaging and relevant.

The contribution of e-Portfolio towards skills related to language, computer, graduate attributes and professional development were also documented in the aforementioned studies. This indicated that apart from academic knowledge, e-Portfolios can be used for industry and practical experiences and even for employment purposes. As such, e-Portfolio is a tool that can be flexibly employed in both formal lessons and informal learning situations.

\section{Conclusion}

The abovementioned studies have established the strengths of applying e-Portfolio in Malaysian higher learning institutions, thereby recognizing its contribution and acknowledging its potential as an educational tool. This review revealed that Malaysian researchers had surveyed the perceptions of relevant stakeholders with regard to the use of the e-Portfolio in higher education. 
Researchers were also aware of the importance for learners to be prepared for the introduction of new tools. This was indicated by the studies that explored learner readiness prior to actual implementation of e-Portfolios. Another aspect that may contribute to the implementation of ePortfolio was learner motivation. The review also revealed that e-Portfolios can be used as a form of assessment, for the purpose of language, to enhance graduate skills, and for the professional development of teachers. In terms of instructional design, Malaysian researchers have contributed to e-Portfolio research by further expanding its use as a mobile application.

Despite the available literature, the implementation of e-Portfolio is still limited to a relatively small number of students and courses. Furthermore, some of the research were in preliminary stages and therefore could not provide concrete data regarding the actual use of e-Portfolio. There is also a tendency to implement e-Portfolio in language and skill related subjects as opposed to science programs. This suggests that there is still much to explore in relation to the use of e-Portfolio in the Malaysian higher education context. As such, future research can look into the application of e-Portfolio involving a larger number of learners as well as a more diverse range of subjects.

\section{References}

Abd-Wahab, S. R. H., Che-Ani, A. I., Johar, S., Ibrahim, M., Ismail, K., \& Mohd-Tawil, N. (2016). EPortfolio as an assessment tool: The development of rubric criteria. Pertanika Journal of Social Sciences \& Humanities, 24 (S): $143-154$.

Abd-Wahab, S. R. H., Che-Ani, A. I., Johar, S., Ismail, K., \& Abd-Razak, M. Z. (2016). ePortfolio: A descriptive survey for contents and challenges.

International Journal of Emerging Technologies in Learning, 11(1), 4-10. https://doi.org/10.3991/ijet.v11i1.4900

Barrett, H. C. (2005). White paper: Researching electronic portfolios and learner engagement. The REFLECT Initiative, 1-26. Retrieved January 3, 2018, from https://www.helenbarrett.com/reflect/whitepaper.pdf

Carl, S. E. (2016). EPortfolios, Google Drive, and Cognitive Process Theory (Master's thesis, Old Dominion University). DOI: 10.25777/c2xn-1239

Challis, D. (2005). Towards the mature ePortfolio: Some implications for higher education. Canadian Journal of Learning and Technology, 31(3). Retrieved from https://www.cjlt.ca/index.php/cjlt/article/view/26488/19670

Chin, C. (2018). Ten schools to join student e-Portfolio trial run next year. The Star Online. Retrieved from https://www.thestar.com.my/news/nation/2018/11/04/ten-schools-tojoin-student-eportfolio-trial-run-next-year

Cooper, T. (1999). Portfolio assessment: a guide for lecturer teachers and course designer. Perth: Praxis Education.

Education Department of Western Australia. (2000). Assessment - portfolios. Education Department of Western Australia. Retrieved from www.eddept.wa.edu.au/centoff/outcomes/focus/fc429.html

Greenberg, G. (2004). The digital convergence: Extending the portfolio model. EDUCAUSE Review, 39(4), 28-37. Retrieved from 
INTERNATIONAL JOURNAL OF ACADEMIC RESEARCH IN PROGRESSIVE EDUCATION AND DEVELOPMENT

Vol. 8, No. 4, 2019, E-ISSN: 2226-6348 @ 2019 HRMARS

http://www.educause.edu/ir/library/pdf/ERM0441.pdf

Hafizan, M., Duggan, P., Tracy, F., \& Stott, T. A. (2015). E-portfolio development and implementation in Malaysian Technical and Vocational Education Training (TVET): A mixed methods analysis of stakeholders' and students' perceptions. International Journal of Arts \& Sciences, 8(1), 243-261.

Khoo, L. M. S., Maor, D., \& Schibeci, R. (2011). The engineering e-Portfolio: Enhancing communication, critical thinking and problem solving and teamwork skills? International Journal of Information and Communication Engineering, 5(5), 788-793. https://doi.org/10.5281/zenodo.1056422

Krause, K. (2006). E-Portfolios for graduate students: A discussion paper. Centre For the Study of Higher Education: University of Melbourne.

Lorenzo, G., \& Ittelson, J. (2005). An overview of e-Portfolios. Educause Learning Initiative. Retrieved January 8, 2018, from https://net.educause.edu/ir/library/pdf/eli3001.pdf

Ministry of Education. (2013). Malaysia education blueprint 2015 - 2025 (higher education). Putrajaya: Kementerian Pendidikan Malaysia.

Mohd, F. M. G., Muhammad, S. S., Nuraihan, M. D., Haslina, H., \& Mohaida, M. (2014). iCollect mobile application for e-portfolio: Experiences from an instructional design perspective. Malaysian Journal of Distance Education, 16(1), $1-14$.

Muhammad, K. K. (2016). Using Facebook as an e-portfolio in enhancing pre-service teachers' professional development. Australasian Journal of Educational Technology, 32(1), 19-31. https://doi.org/10.14742/ajet.2052

Nambiar, V. G. K., \& Melor, M. Y. (2017). Reflective practice with e-portfolio. Malaysian Journal of ELT Research, 13(1), 43-54.

New Zealand Ministry of Education. (2011). Digital portfolios: Guideline for beginners. Wellington: New Zealand Ministry of Education.

Rokhsareh, M., Azizah, A. R., \& Mojib, M. (2015). Electronic portfolio motivational factors from students' perspective: A qualitative study. Knowledge Management \& E-Learning, 7(2), 265-279. https://doi.org/10.34105/j.kmel.2015.07.017

Sadia, Y. A. (2005). An introduction to electronic portfolios in the language classroom. Retrieved from http://iteslj.org/Techniques/Ali-Portfolios.html

Shalini, S. B., Wan, F., A. W. M., Mahani, S., \& Mohamad, H. Z. (2012). Digital portfolio and professional development of language teachers. Procedia - Social and Behavioural Sciences, 66(7), 176-186. https://doi.org/10.1016/j.sbspro.2012.11.259

Stannard, R., \& Basiel, A. S. (2013). A practice-based exploration of technology enhanced assessment for English language teaching. In Motteram, G (Ed.), Innovations in learning technologies for English language teaching (pp.145-174). London: British Council.

Syamsul N. A. M., Mohamed A. E., \& Norazah, N. (2015a). Are students ready to adopt ePortfolio? Social science and humanities context. Asian Social Science, 11(13), 269-275. http://dx.doi.org/10.5539/ass.v11n13p269 
Syamsul, N. A. M., Mohamed, A. E., \& Norazah, N. (2015b). Determining e-Portfolio elements in learning process using fuzzy delphi analysis. International Education Studies, 8(9), 171176. http://dx.doi.org/10.5539/ies.v8n9p171

Syamsul, N. A. M., Mohamed, A. E., \& Norazah, N. (2016). Designing an e-Portfolio as a storage, workspace and showcase for social sciences and humanities in higher education institutions (HEIs). Asian Social Science, 12(5), 185-194.

http://dx.doi.org/10.5539/ass.v12n5p185

Thang, S. M., Lee, Y. S., \& Nurul, F. Z. (2012). The role of the electronic portfolio in enhancing information and communication technology and English language skills: The voices of six Malaysian undergraduates. Computer Assisted Language Learning, 25(3), 277-293. https://doi.org/10.1080/09588221.2012.655299 